\title{
INFLUENCE OF THE ECOLOGICAL CONDITIONS ON THE PRODUCTIVE POTENTIAL OF GREY ALDER
}

\author{
UTJECAJ EKOLOŠKIH UVJETA NA PROIZVODNI \\ POTENCIJAL SIVE JOHE
}

Michal BUGALA, Zuzana PAROBEKOVÁ, Ján PAROBEK

\begin{abstract}
Summary
The aim of the study is to analyse the productive potential of grey alder (Alnus incana (L.) Moench) along an altitudinal gradient to verify coincidence of productive and ecological optimum and to identify climatic factors that control the growth. Along the altitudinal gradient of the river basin, dendrometric data has been analysed on the eight permanent research plots at the altitude of 525-705 m. Correlations between standard chronology and average monthly climate characteristics were calculated for the period 1969-2015. Significant differences in the average basal area increments have been recognized among the investigated altitudinal zones. The highest basal area increment $\left(1661 \pm 975 \mathrm{~mm}^{2} \mathrm{y}^{-1}\right)$ was detected in the zone of altitude $605 \mathrm{~m}$. and the average annual volume increment of the model grey alder stand was $4.59 \mathrm{~m}^{3}$. The radial growth of grey alder has been positively affected only by the temperature of the current April and negatively by precipitation of the previous growing season. Based on the pointer year analysis can be claimed that condition of the root system is the most influential factor in relation to the radial growth and is dependent on water stress in the previous year. Investigated relationships may significantly influence decision making process in the forest management focused on grey alder re- or afforestation.
\end{abstract}

KEY WORDS: production, ecological optimum, basal area increment, dendrochronology, climate-growth relationships

\section{INTRODUCTION}

\section{UVOD}

Grey alder (Alnus incana (L.) Moench.) is an important component of riparian vegetation with great regulatory and retention ability during high water levels. In the spring areas alder stands are a specific habitat most commonly found on the upper parts of watercourses (Lukáčik, 1996; Lukáčik and Bugala, 2005; Vukelić et al., 2012). These stands not only affect the steadfastness of the watercourses and retain their natural character, but they are significant landscape element. Grey alder belongs to the fast-growing tree species with ameliorative function and considerable tolerance to various climatic and edaphic environmental conditions (Rodríguez-González et al., 2010; Pernar et al., 2012; Vacek et al., 2016). It is often used for the biological site preparation and serves for the soil stabilization, regulation of the microclimate (mitigation of temperature extremes), and improvement of the physical, chemical and biological soil properties. Symbiotically $\mathrm{N}_{2}$-fixing and litter decomposition significantly improve the quality of the soils where it grows. During the last decades this unique combination of properties has made grey alder as the tree species of an increasing importance in Europe (Rytter and Rytter, 2016). 
Since 2004, Slovakia has been involved in the rural development programs aimed at increasing of the habitats productivity, ensuring ecological stability in the upward climate change and better utilisation of the potential of the country to maximize $\mathrm{CO}_{2}$ sequestration (APA, 2015). An important tool is an afforestation of non-forest land (unsuitable for agricultural production or in the public interest associated with the greening of the landscape) by fast-growing species. At the same time, it increases the pressure on the use of woody biomass as a renewable energy resource. In the planning of economic exploitation of grey alder, it is necessary to find the productive optimum of species in the local conditions. Achievement of adequate quantity and quality of the production within the shortest possible time and reviewing the factors affecting the production represent a key moment in the decision-making. Knowledge gained from the analysis of grey alder natural populations pointed out differences in the production potential based on the rising altitude or the fluctuation of groundwater table (Douda et al., 2009; Rodríguez-González et al., 2010; Bugala and Parobeková, 2016). From the view of the ecological stability, in afforestation, it is necessary to use tree species in the zone of their ecological optimum, which does not necessarily coincide with their productive optimum. Trees growing in the ecological optimum are less sensitive to the external factors and their growth is evener (Pernar et al., 2012). Their ecological valence to the climatic changes is then much greater. This is very important for the local scale where forest management plans (e.g., tree species selection) and river engineering measures need to be established and adapted in order to mitigate global climate change (Rieger et al., 2017). Optimums consistency or determining of their priorities become an actual question.

Dendroecological studies represent an appropriate solution to the mentioned scientific tasks (Bojaxhi and Toromani, 2016, 2017). They allow describing the dynamic of stand growth in the past by measuring the widths of tree rings or other parameters of increase and identify the climatic fac- tors that control tree growth (Rozas et al., 2005). The main commonly monitored factors limiting the growth of woody plants are temperature and precipitation. The radial growth of tree is usually affected by temperatures and precipitation in the year of the growth as well as in the year preceding the formation of the tree ring (Speer 2010; Rybníček et al., 2012). Tree species often produce vessels at the beginning of the growing season before leaf-out, suggesting that these vessels develop from cambial derivatives from a favourable previous growing season that overwintered in an undifferentiated state (Speer, 2010). Direct influence of temperature on the growth mainly occurs at the beginning of the growing season when low temperature can postpone the beginning of the cambial activity. On the other side, existing research reveals, that alders are generally little sensitive to the precipitation in the current period due to nearby groundwater table (Bugala and Parobeková, 2016; Vacek et al., 2016). The conditions of root system may negatively depend on the precipitation of the previous periods, since high level of groundwater table causes its strong damage (Dittert et al., 2006; Rodriguez-Gonzales et al., 2010).

This study is part of a long-term research of naturally occurring black and grey alder stands in Slovakia. The aims of the study are 1) to analyse the productive potential of grey alder along an altitudinal gradient 2) to verify coincidence of the productive and ecological optimum and 3) to identify the climatic factors that control the growth of grey alder. These findings are necessary for the purposes of forthcoming afforestation of non-forest land or for reforestation of the endangered areas.

\section{MATERIAL AND METHODS MATERIJAL I METODE}

\section{Site description - Područje istraživanja}

The study was conducted in the Great Fatra Mts belonging to the Western Carpathians (Figure 1). The data were collec-

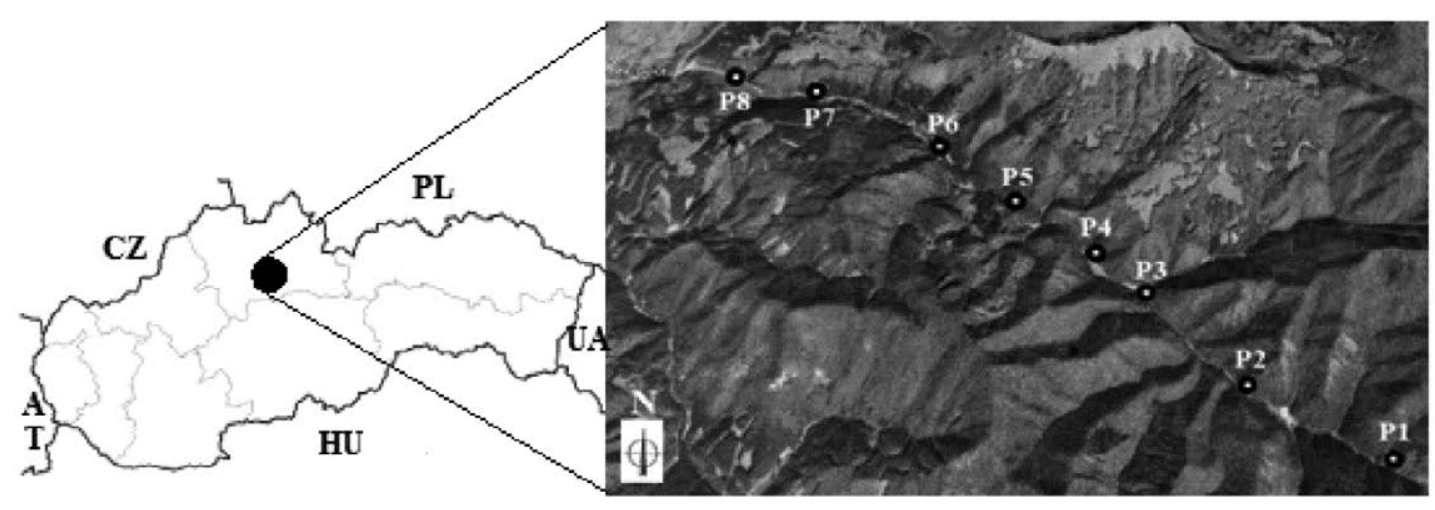

Figure 1. Location of permanent research plots (P1-P8) in the area of the Belianska Valley

Slika 1. Lokacija trajnih istraživačkih ploha (P1-P8) u području doline Belianska 
ted at 8 permanent research plots (PRP) in the basin of the creek in the Belianska Valley. All PRPs represented natural unmanaged riparian stands dominated by grey alder (Alnus incana (L.) Moench.). European ash (Fraxinus excelsior (L.)), sycamore maple (Acer pseudoplatanus (L.)) and black alder (Alnus glutinosa (L.) Gaertn.) are associated with the grey alder stands in the lower parts of the valley (forest plant communities Alnetum incanae and Fraxineto-Alnetum). The predominant soil type was Fluvisol formed on the clayey or gravel alluvial deposits. According to the altitudinal gradient (500-700 m), the Belianska Valley is characterised by moderately warm to cool mountainous climate (Köppen climate classification) with average July temperature $10-17^{\circ} \mathrm{C}$, average January temperature from -3 to $-9^{\circ} \mathrm{C}$, precipitation during the growing season $450-650 \mathrm{~mm}$ and precipitation during the winter season $300-350 \mathrm{~mm}$. A number of days with snow cover is 120-140 (Lukniš et al., 1972).

\section{Data collection and analyses - Prikupljanje i analiza podataka}

Data were conducted in 2015 after the growing season. Series of circular PRPs (P1-P8 (P1: 4857'39.65" N, 1905'26.43" E, P8: $\left.48^{\circ} 59^{\prime} 55.20^{\prime \prime} \mathrm{N}, 19^{\circ} 00^{\prime} 17.97^{\prime \prime} \mathrm{E}\right)$ ) wereas designed to capture the entire river basin (Figure 1). According to the altitudinal gradient and incidents of grey alder populations, PRPs were established at an altitudinal step of $20-30 \mathrm{~m}$. The lowest located plot P8 was at the altitude of $525 \mathrm{~m}$ and the highest located P1 at $705 \mathrm{~m}$. It was the highest incidence of grey alder in the investigated basin. Centres of circular PRPs covering an area of $150 \mathrm{~m}^{2}$ with radius of $7.5 \mathrm{~m}$ were situated 10-14 $\mathrm{m}$ from the bank of the creek depending on the alluvial width at an inclination of $2-4 \%$.

In each sample plot, diameter at the breast height (dbh) and the tree height $(\mathrm{h})$ were measured for all standing trees with $\mathrm{dbh} \geq 8 \mathrm{~cm}$. Other variables (basal area increment, volume increment) were calculated for each plot and expressed per hectare. At each plot, increment cores were extracted from three co-dominant trees with dbh nearest to the mean stem (Fabrika and Pretch, 2011), at the breast height by the Pressler borer, perpendicularly to the trunk axis. All increment samples were processed by standard dendrochronological procedures (Cook and Kairiukstis, 1992). Samples were scanned by the Epson Expression 10,000 XL scanner. Ring widths were measured to the nearest $0.001 \mathrm{~mm}$ using the WinDENDRO ${ }^{\mathrm{TM}}$ software. Since the age of individuals did not exceed 50 years (relatively short tree-ring series), ring-width series could be cross-dated by the Skeleton plotting technique (Cropper, 1979) using WinDENDRO ${ }^{\mathrm{TM}}$ software. The output from ARSTAN (Cook, 1985) summarised descriptive statistics for final chronologies of all PRPs (row site chronologies) and whole basin (raw and standard chronology). Tree-ring width series were detrended by the Hugershoff growth curve (procedure of growth trend removal).
In order to identify climate factors controlling the tree growth, correlations between standard chronology and mean monthly climate characteristics were computed for the period 1969-2015. The correlations were performed in the 19-month window, from the previous April to the current October. The climate of this period is one of the major influences on the radial increment in each particular year (Rybníček et al., 2012). Monthly precipitation sums and average monthly temperatures were obtained from CRU TS3.21 (0.5 x 0.5 grid interpolated points) available at the KNMI Climate Explorer (Harris et al. 2014; http://climexp. knmi.nl).

To eliminate variability in the growth due to the influence of different thickness, the increment of the basal area (BAI) was calculated for each individual (Phipps and Whiton, 1988).

$$
\begin{gathered}
r_{t}=r_{(t-1)}+w_{t} \\
B A I_{t}=\pi\left(r_{t}^{2}-r_{(t-1)}^{2}\right)
\end{gathered}
$$

$t$ - age of the tree, $r_{t}-$ tree radius et age $t, w_{t}$ - tree-ring width in age $t, \mathrm{BAI}_{\mathrm{t}}$ - basal area increment in age $t$

From all $\mathrm{BAI}_{\mathrm{t}}$ values in the stand, the average basal area increment $\left(\mathrm{BAI}_{\mathrm{av}}\right)$ and the value of its standard deviation (sd) were calculated. For the calculation of the average stand basal area increment $\left(\mathrm{BAI}_{\mathrm{s}}\right), 530$ dominant and codominant individuals were considered. This value was the average frequency of trees from the range $490-570$ pcs per ha. For the calculation of the average annual volume increment of the stand $\left(\mathrm{i}_{v}\right)$ the $\mathrm{BAI}_{\mathrm{s}}$ values were multiplied by the average heights of individuals in PRPs and reduced by the form factor. In the area of the study form factor of grey alder present the value 0.44 . The differences in biometric characteristics of PRPs were tested by one-way analysis of variance followed by Duncan's test.

Radial increments homogeneity (Py) was evaluated by the Pointer year's method (Schweingruber, 1996). It is an accepted method of showing annual growth reactions due to abrupt changes in the environmental conditions especially due to climatic variations.

$$
P y=\frac{w_{t}-\frac{w_{(t-2 ; t+2)}}{5}}{s_{x(t-2 ; t+2)}}
$$

$\mathrm{w}_{\mathrm{t}}$ - tree ring width at age $\mathrm{t}, \mathrm{s}_{\mathrm{x}}$ - standard deviation of tree ring widths in the selected period (in this case 5 years)

The pointer years are identified as years that refer to the extreme growth response. For specific pointer year identification, the percentage of trees that revealed either positive or negative growth response in the studied year was taken into consideration. The level of the threshold depends on the aim 
Table 1. Biometric characteristics of grey alder stands Tablica 1. Biometrijske značajke sastojina sive johe

\begin{tabular}{|c|c|c|c|c|c|c|c|}
\hline plot & $\begin{array}{c}\mathrm{h} \\
(\mathrm{m})\end{array}$ & (cm) & $(\mathrm{mm})$ & $\begin{array}{l}W_{\text {rmax }} \\
(\mathrm{mm})\end{array}$ & $\begin{array}{c}\mathrm{BAl}_{\mathrm{av}} \\
\left(\mathrm{mm}^{2} \mathrm{y}^{-1}\right)\end{array}$ & $\begin{array}{c}\mathrm{BAl}_{\mathrm{S}} \\
\left(\mathrm{m}^{2} h \mathrm{a}^{-1} \mathrm{y}^{-1}\right)\end{array}$ & $\begin{array}{c}i_{v} \\
\left(m^{3} h a^{-1} y^{-1}\right)\end{array}$ \\
\hline P1 & $19.2 \pm 0.7$ & $31.2 \pm 2.6$ & $2.5 \pm 1.5$ & 9.0 & $897 \pm 471$ & 0.48 & 4.29 \\
\hline P2 & $20.9 \pm 0.9$ & $28.1 \pm 2.7$ & $2.5 \pm 1.5$ & 6.7 & $737 \pm 330$ & 0.39 & 3.84 \\
\hline P3 & $14.7 \pm 1.8$ & $24.4 \pm 2.2$ & $2.7 \pm 1.4$ & 7.3 & $822 \pm 455$ & 0.44 & 3.01 \\
\hline P4 & $15.5 \pm 1.9$ & $31.8 \pm 2.8$ & $2.9 \pm 1.8$ & 10.6 & $1052 \pm 500$ & 0.56 & 4.07 \\
\hline P5 & $15.5 \pm 1.1$ & $28.9 \pm 3.2$ & $4.1 \pm 1.8$ & 14.0 & $1661 \pm 975$ & 0.88 & 6.41 \\
\hline P6 & $15.5 \pm 1.1$ & $26.3 \pm 2.5$ & $3.5 \pm 1.6$ & 10.4 & $1498 \pm 747$ & 0.79 & 5.78 \\
\hline P7 & $17.2 \pm 1.2$ & $35.7 \pm 3.5$ & $2.4 \pm 1.7$ & 7.8 & $804 \pm 543$ & 0.43 & 3.44 \\
\hline P8 & $18.2 \pm 1.3$ & $25.0 \pm 2.3$ & $3.6 \pm 2.5$ & 10.1 & $1301 \pm 690$ & 0.69 & 5.90 \\
\hline
\end{tabular}

$\mathrm{h}$ - average tree height, $\mathrm{dbh}$ - average diameter at breast height, $\mathrm{w}_{\mathrm{r}}$ - average tree ring width, $\mathrm{w}_{\mathrm{r} \text { max }}-$ maximal tree ring width; $\mathrm{BAl}_{\mathrm{av}}-$ average basal area increment, $\mathrm{BAl}_{\mathrm{s}}$ - average stand basal area increment, $\mathrm{i}_{\mathrm{v}}$ - average stand volume increment

$h$ - prosječna visina stabla, dbh - prosječni promjer na prsnoj visini, wr - prosječna širina goda, wr max - maksimalna širina goda, BAlav - prosječni rast temeljnice, $B A / s$ - prosječni rast temeljnice sastojine, iv - prosječni rast volumena sastojine

of the study (Schweingruber et al., 1990). In our case, thresholds of $\mathrm{Py} \geq 1$ for positive and $\leq-1$ for negative pointer year was selected. The pointer year was considered when an extremely narrow or wide tree-ring was detected in at least $40 \%$ of trees per site (Cropper, 1979; Douda et al., 2009).

\section{RESULTS}

REZULTATI

Basic biometric characteristics of the investigated stands are presented in Table 1. Stands are 28-47 years old, considerably uniform of small diameter and height differentiation. The chronologies are calculated based on 24 series (Table 2). Mean tree diameter of the basin is $27.6 \mathrm{~cm}$, with a standard deviation of $3.6 \mathrm{~cm}$ and mean tree height is $17.0 \mathrm{~m}$ with a standard deviation of $2.1 \mathrm{~m}$. Mean tree-ring width is 3.1 $\mathrm{mm}$. In terms of production possibilities, maximal ring width $14.0 \mathrm{~mm}$ recorded on the plot P5 is interesting. On this plot the highest average tree-ring width $4.1 \pm 1.8 \mathrm{~mm}$ has also been found. Obvious it is the most productive plot. Due to the impact of the size of individuals on assessment of their incremental possibilities comparison of $\mathrm{BAI}_{\mathrm{av}}$ values appear more appropriate. According to comparison of all eight PRPs, the growth trend along the altitudinal gradient is clearly visible and confirmed by the statistical testing (Figure 2). The results of one-way analysis of variance confirm a statistically significant effect of the altitude on the dynamic of the diameter increment. The highest value of $\mathrm{BAI}_{\mathrm{av}}$ is observed in the individuals located at an altitude of $605 \mathrm{~m}$. (P5), whereas the lowest $\mathrm{BAI}_{\mathrm{av}}$ value is observed at an altitude of $685 \mathrm{~m}$. (P2).

After recalculating of BAIav per hectare values for the model stand and to stand volume increment the same trend is maintained (Table 1). Again, a significant culmination at an altitude of $605 \mathrm{~m}$ (P5) is evident. Average volume increment of all grey alder stands is $4.59 \pm 1.26 \mathrm{~m}^{3} \mathrm{ha}^{-1} \mathrm{y}^{-1}$.
Basic characteristics of raw tree-ring series from the investigated plots are summarised in Table 2. It is worth mentioning, that the most productive plot $\mathrm{P} 5$ shows at the same time the lowest value of mean series sensitivity (MSs) and the highest values of Gleichläufigkeit $(G)$. These facts present generally low variability in the tree ring widths and simultaneously a common trend in the growth. It means that grey alder finds here its ecological optimum. Values of between-tree correlation (RBT) and expressed population signals (EPS) are generally high and confirm rather good agreement between individual series at all sites and relatively low influence of non-climatic factors.

The correlation of raw chronology with temperature in a current year is significantly negative. It is caused by fast decreasing growth trend and generally increasing temperatures. Decreasing raw chronology and gradually increasing April

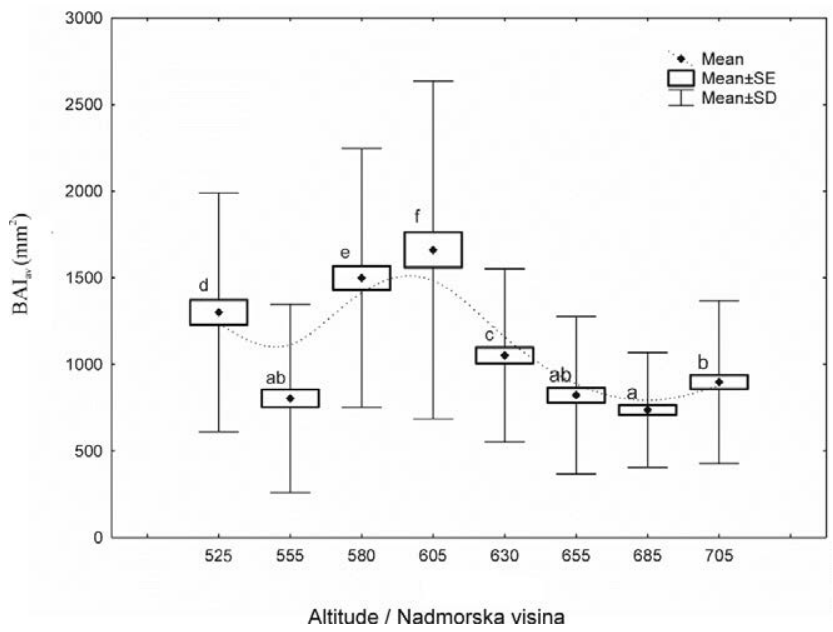

Figure 2. Average basal area increments $\left(\mathrm{BAl}_{\mathrm{av}}\right)$ of grey alder according to the altitudinal zones. Letters represent similarity between plots according to Duncan test

Slika 2. Prosječni rast temeljnice $\left(\mathrm{BAl}_{\mathrm{av}}\right)$ sive johe ovisno o nadmorskoj visini. Slova predstavljaju sličnost među plohama prema Duncanovom testu 
Table 2. Dendrochronological characteristics of raw site chronologies

Tablica 2. Dendrokronološke značajke grube kronologije

\begin{tabular}{|cccccccc} 
PRP & MSL & MSs & AC1 & RBT & G & 0.81 .82 & \\
P1 & 45 & 0.31 & 0.70 & 0.71 & 88.21 & 0.85 \\
P2 & 42 & 0.32 & 0.68 & 0.66 & 86.38 & 0.82 \\
P3 & 38 & 0.27 & 0.73 & 0.60 & 88.89 & 0.94 \\
P4 & 40 & 0.25 & 0.83 & 0.84 & 96.55 & 0.90 \\
P5 & 31 & 0.23 & 0.86 & 0.76 & 93.33 & 0.91 \\
P6 & 39 & 0.26 & 0.76 & 0.77 & 93.94 & 0.89 \\
P7 & 38 & 0.29 & 0.67 & 0.73 & 0.32 & 0.85
\end{tabular}

MSL - Mean series length, MSs - Mean sensitivity of series, AC1 - First-order autocorrelation, RBT - Mean between-tree correlation, G - Gleichläufigkeit, EPS - Expressed population signal

MSL - srednjak serije dužine, MSs - srednjak osjetljivosti serija, AC1 - autokorelacija prvog reda, RBT - srednja korelacije među stablima, G - Gleichläufigkeit, EPS izdvojeni signal populacije

temperatures are visible in Figure 3 (above). To remove a growth trend detrended standard chronology is used (Figure 3 below). The statistics are given in the Table 3 .

Statistically significant standard chronology correlation with temperature is recorded for April (positive) and with
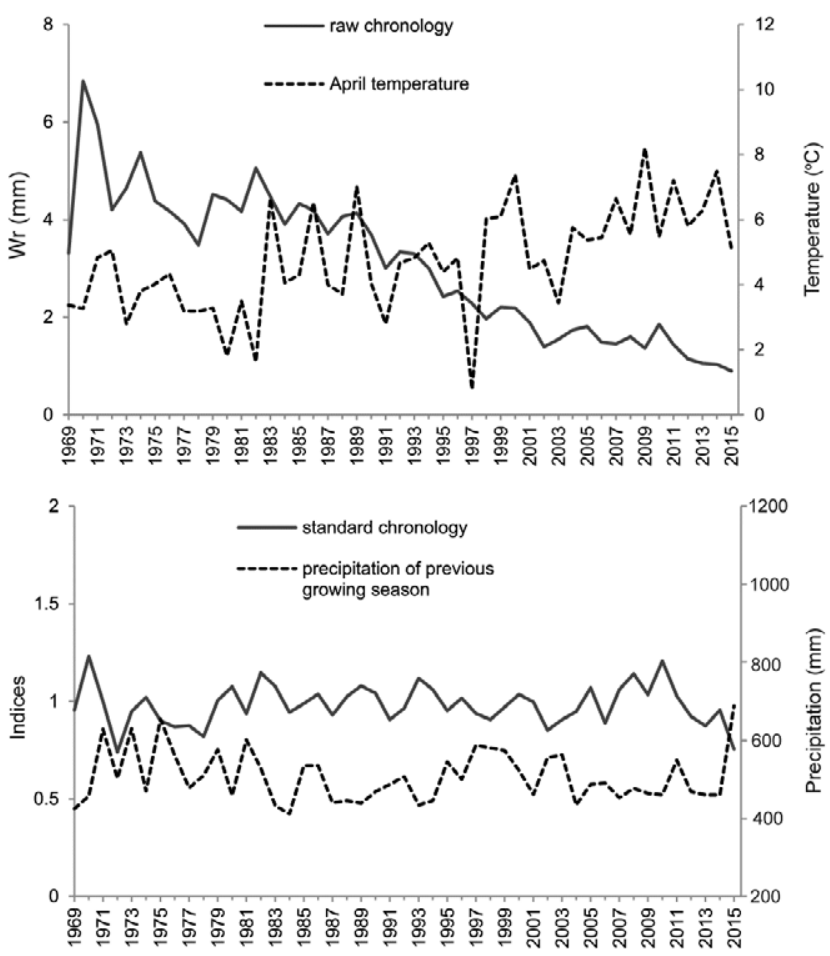

raw chronology/gruba kronologija, April temperature/temperature $u$ travnju, standard chronology/standardna kronologija, precipitation of previous growing season/kolicina padalina prethodne vegetacijske sezone, indices/indeksi, precipitation/padalina, temperature/temperatura, Wr/prosječna širina goda

Figure 3. Courses of raw (above) and standard (below) chronologies compared with courses of April temperatures and precipitations of previous growing seasons

Slika 3. Trendovi grube (gore) i standardne (dolje) kronologije u usporedbi sa trendovima temperature u travnju i količine padalina u prethodnoj vegetacijskoj sezoni precipitations for a previous growing season (negative) (Table 3, Figure 4). Courses of the standard chronology, April temperatures and precipitations of previous growing seasons are shown in Figure 3. Correlations of the standard chronology with monthly precipitations are mostly negative (Figure 4). Positive although insignificant correlations are recorded for summer months. Correlations with monthly temperatures are mostly positive. High temperatures in October affect growth in a considerably negative way.

Growth sensitivity of the analysed individuals of grey alder in the whole basin is shown in Figure 5. From the analysis of pointer years relatively low degree of sensitivity to the external factors is evident. The average intensity of the positive year expressions is $15.37 \%$ and of the negative year

Table 3. Descriptive statistics of the raw and standard chronology of whole basin for the common period (1969-2015)

Tablica 3. Deskriptivna statistika grube i standardne kronologije cijelog bazena za promatrani period (1969 - 2015)

\section{Raw chronology / gruba kronologija}

Number of series / broj serija

24

Mean series length / srednjak serije dužine (MSL)

38

Mean tree-ring width / srednja širine goda (TRW)

3.055

Standard deviation of TRW / standardna devijacija TRW (SD)

1.450

Mean sensitivity of series / srednjak osjetljivosti serija (MSs)

0.143

First-order autocorrelation / autokorelacija prvog reda (AC1)

Standard chronology / standardna kronologija

Mean between-tree correlation / srednjak korelacije među drvećem (RBT)

Expressed population signal / izdvojeni signal populacije (EPS)

\section{Climate response / odgovor na klimatske promjene}

Precipitation of previous growing season / količina padalina prethodne vegetacijske sezone

Current April temperature / temperature $u$ travnju 
口Temperature aPrecipitation

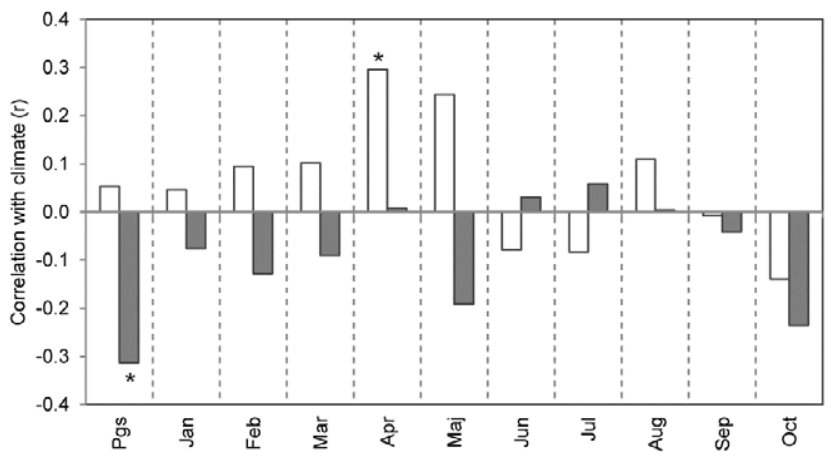

temperature/temperatura, precipitation/padalina, correlation with climate/klimatske korelacije

Figure 4. Values of the correlation coefficient of the standard chronology with average monthly temperatures and precipitations from the previous growing season (Pgs) to October of the current year for the period of 1969-2015, values with an asterisk are statistically significant $(\mathrm{p}<0.05)$

Slika 4. Vrijednosti koeficijenta korelacije standardne kronologije sa srednjim mjesečnim temperaturama i količinom padalina za prethodnu vegetacijsku sezonu (Pgs) do listopada tekuće godine za period 1969-2015, vrijednosti sa zvjezdicom pokazuju značajnu statističku razliku $(p<0.05)$

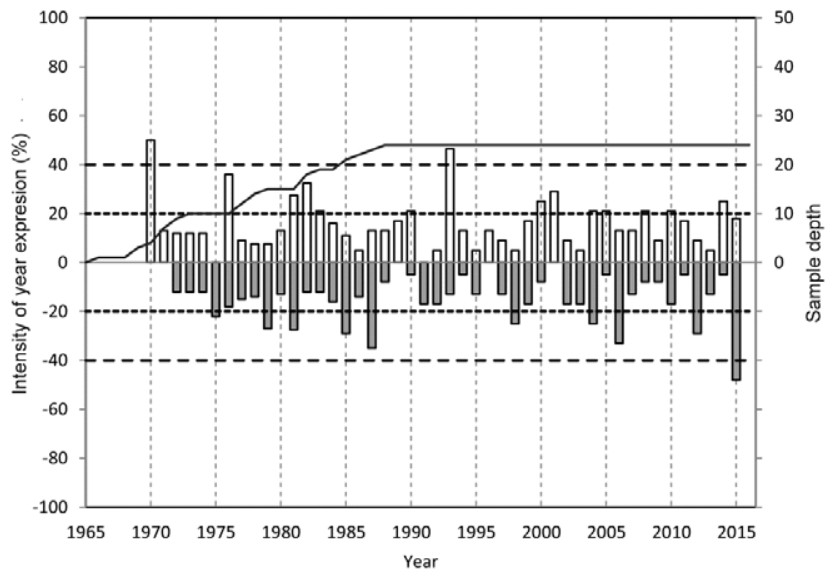

intensity of year expression/intenzitet godišnjeg izražavanja, year/ godina, sample depth/ veličina uzorka

Figure 5. The grey alder growth sensitivity to external signals expressed by pointer years

Slika 5. Osjetljivost rasta sive johe na vanjske signale izražene prema metodi referentne godine

$14.46 \%$. Significantly positive growth response (over $40 \%$ of trees) was two times recorded $(1970,1993)$ and negative only once (2015).

\section{DISCUSSION RASPRAVA}

The evaluation of basic biometric characteristics reveals that grey alder creates homogeneous stands in terms of species composition and vertical and diameter structure. The average age and diameter of surveyed individuals ranged be- tween 28 and 47 years and 24.4 and $36.3 \mathrm{~cm}$ and the height ranged between 14.7-20.9 $\mathrm{m}$ (Table 1). The number of individuals also varied only in the narrow range of 490-570 pcs.ha $^{-1}$. Similar results in the assessment of the height and diameter variations of the alder natural populations were gained by Bugala and Pittner, (2010) and Bugala and Parobeková, (2016) in other regions of Slovakia. They stated that the alder's growth strongly depends on the light, so decreasing growing space of individuals starts processes of autoreduction and dying of the undersized trees. These processes result in a single-layer composition with the low height variation in all studied stands. Vacek et al., (2016) confirm homogenous vertical and diameter structure even with a much higher number of individuals per ha (556-828 trees per ha) in Sudetes Mts. in the Czech Republic.

Radial increment strongly depends on age and altitude. Fast-growing features of grey alder lead to the very intensive growth between 5-20 years of age and to a shortened lifespan at the level of 50-60 years (Pagan, 1996). In the surveyed basin, the radial increment in the first 20 years markedly fluctuated (1969-1989) and in the next 26 years decreased relatively fast until it dropped to less than one-quarter (Figure 3 above). Mentioned fact manifests favourable environmental conditions, which allows faster growth in early years but accelerates the onset of senescence. Higher ability of young individuals (up to 20 years) to respond to the external factors was also manifested. Young trees might respond faster to the changes in temperature due to higher growth rate and earlier onset of xylogenesis (Li et al., 2012). At the same time, Fang et al., (2015) describe the sensitivity of the young trees to the drought caused by low precipitation, although this would not be a threat to the riparian stands of the surveyed region, since mountain watercourses are permanent there (Blaškovičová et al., 2011).

Along the rising altitude, the highest average tree ring width is noticed at altitude of $605 \mathrm{~m}(4.1 \pm 1.8 \mathrm{~mm})$. Influence of altitudinal gradient is well portrayed by the trend of average basal area increment (Figure 2). In the observation of the $\mathrm{BAI}_{\mathrm{av}}$ along the altitudinal gradient, obviously, it ranges between $736.7 \pm 330 \mathrm{~mm}^{2} \mathrm{y}^{-1}$ at an altitude of $685 \mathrm{~m}$ and $1660.7 \pm 975 \mathrm{~mm}^{2} \mathrm{y}^{-1}$ at an altitude of $605 \mathrm{~m}$, where it evidently culminates. Advancing of trend curve in the lowest and the highest elevation (P8, P1) is probably due to the proximity of debris dams affecting the microclimate conditions, a level of ground water-table and also an amount of nutrients. According to obtained results, the production optimum of the grey alder in the studied river basin is situated at the altitudes around $605 \mathrm{~m}$ (volume increment $6.41 \mathrm{~m}^{3} \mathrm{ha}^{-1} \mathrm{y}^{-1}$ ), but neither here its production does not reach the production of other commercial tree species. The average volume increment of the investigated river basin $4.59 \mathrm{~m}^{3} \mathrm{ha}^{-1} \mathrm{y}^{-1}$ is comparable with average volume increment 
of Bukovské vrchy Mts., which are located in the east part of Slovakia - $4.18 \mathrm{~m}^{3} \mathrm{ha}^{-1} \mathrm{y}^{-1}$ (Bugala and Parobeková, 2016) and also with Sudetes Mts. in the Czech Republic, where increment ranges between $3.53-5.59 \mathrm{~m}^{3} \mathrm{ha}^{-1} \mathrm{y}^{-1}$ (Vacek et al., 2016). Shift of production optimum in Bukovské vrchy Mts was due to higher continentalism of the climate. There, the highest volume increment was $5.25 \mathrm{~m}^{3} \mathrm{ha}^{-1} \mathrm{y}^{-1}$ at an altitude of $400 \mathrm{~m}$, which was more than $200 \mathrm{~m}$ of altitude lower. An altitude in which grey alder achieves its productive optimum therefore strongly depends on locality, and it should be considered also in the management plans and in greening projects. On the other side, in terms of potential economic use of alder stems, the most important indicator is their overall quality. Quality features are usually influenced by age and origin of individuals, their genetic conditionality, but also sociological position in the stand. Increasing interest in grey alder gives more attention to saving the gene pool of its valuable populations and searching for appropriate ways of its renewal and cultivation (Krstinić et al., 2002, Šmelková and Sarvašová, 2007). With proper treatment, alder stems of high quality are achievable even on sites, where other species are unable to thrive (Bugala and Migas, 2011). Since grey alder belongs to the noble woods, its value production may outweigh the volume production of other commercial tree species.

In the context of greening projects, in recent years, the issue of ecological suitability and stability has also come to the fore (APA, 2015). Grey alder growing in the zone of its ecological optimum seems to be a very good alternative in choosing suitable tree species for this purpose (Rytter and Rytter et al., 2016). In our case, based on the characteristics of raw tree-ring series (Table 2), ecological optimum of grey alder is identical with its productive optimum, what is the undisputed advantage of this tree species. Low growth sensitivity of the whole population (0.143) refers to its ability to cope with the external factors and fairly wide ecological elasticity. As the between-tree correlation and expressed population signal confirm the low influence of non-climatic factors, a substantial part of the sensitivity is caused by the climatic factors. The growth trend of grey alder in the surveyed river basin is strongly decreasing and air temperatures are gradually increasing which makes them significantly negatively correlated (Figure 3 above). Standard chronology eliminates the growth trend influence; nevertheless, it is possible that increasing temperature can potentially slightly change correlation coefficients in time with the progressive global warming (Parobeková et al., 2016). Descriptive statistics indicate that the quality of standard chronology of grey alder is comparable with the other chronologies of broad-leaf trees from the temperate zone of Europe (Rozas, 2005; Douda et al., 2009). Expressed population signal (EPS) 0.85 reflects that the standard chronology is dominated by a coherent stand-level signal and is suitable for climate reconstruction (Speer, 2010). Growth-climate analysis provides generally weak correlations between temperatures and precipitations for the growing period 19692015 . The radial growth of grey alder was significantly positively affected only by temperature in the current April and negatively by precipitation in the previous growing season. Also, Vacek et al. (2016) recorded positive influence of temperature and negative impact of precipitation. Therefore, some insignificant correlations were recorded in other months. Generally, it can be stated, that grey alder growing near to the watercourse prefers drier and warmer spring and colder and drier autumn. Negative influence of the precipitations in the previous growing season is linked to the root system condition. Long-term soil saturation causes anaerobiosis in the rooting zone and the root system may be strongly damaged (Rodriguez-Gonzales et al., 2010). Then there is a decrease in the nitrogen fixation and nutrient intake, increase in the concentration of toxic minerals in soil and deceleration of photosynthesis (Dittert et al., 2006). All these processes are associated with lower annual ring increment in the current year and are even more pronounced in the next year. The damaged root system cannot adequately supply the tree and despite favourable conditions in the next year, the tree lagging behind in the radial growth.

Pointer year analysis uncovers, that population responded to the climate significantly positive twice - in 1970 and 1993, and negative only once - in 2015. On the average, only around $30 \%$ of trees revealed positive or negative reaction to the external factors, like we stated above mainly on climate. Similar results were obtained also in other localities of Slovakia (Balanda et al., 2012; Bugala and Parobeková, 2016). Indeed, several dendroclimatic studies have shown a relatively weak relationship between annual tree growth and climate in wetlands (Linderholm, 1999; Linderholm and Leine, 2004; Douda et al., 2009; Vacek et al., 2016). Both positive pointer years enveloped under different conditions of the current years (1970 - cold and wet, 1993 cold and dry (Harris et al. 2014; http://climexp.knmi.nl)) but they followed after dry previous growing seasons. The increment of negative pointer year enveloped under warm and drier climate conditions, which are according to our results favourable for the growth of grey alder in the riparian zone, but extremely wet previous growing season caused probably the aforementioned damage of the roots. It follows that condition of the root system is the most influential factor in relation to the radial growth and it depends on water stress in the previous year. On the other hand, very warm and dry year 1992 (previous year of the positive pointer year 1993) (Figure 3), is mentioned in dendroecological studies of other tree species (Rybníček et al., 2012), but always in the connection with growth reduction. At surveyed locality, only $18 \%$ of individuals reported a reduction of growth, what confirms that individuals of grey alder can 
eliminate the negative impact of lack of precipitation by a sufficient supply of groundwater.

The information obtained in this study is relevant in terms of better knowledge of the growth characteristics and ecology of the taxa, as well as in terms of the practical application of the grey alder populations in the forest and landscape management. Positive ameliorative effect on soil and microclimate are most known and utilized functions, but recently also stabilizing function comes into the foreground. This function is used in conversions of tree species composition of endangered forest ecosystems, especially of foothill spruce forests. Grey alder gains an importance in the formation of stabilizing belts in the endangered areas (Marhefka, 2014). Using grey alder on areas outside the river basin, e.g. for afforestation of non-forest land or in stabilizing belts, probably totally eliminates the negative impact of precipitations on the root system. It will cease likely to be negatively affected by precipitations of the previous year and will be sensitive to the precipitations of the current year.

\section{ACKNOWLEDGEMENTS ZAHVALA}

This study was supported by projects of Scientific Grand Agency of the Ministry of Education - VEGA 1/0040/15 and VEGA 1/0492/17.

\section{REFERENCES}

\section{LITERATURA}

- APA 2015: Slovakia - Rural Development Program (National), Version of 1.3.2015.http://www.apa.sk/index.php?start\&navID=496

- Balanda, M., M. Bugala, I. Lukáčik, 2012: Productive potential of black alder (Alnus glutinosa (L.) Gaertn.) in the Kremnica Mountains, Acta Pruhoniciana, 102: 25.-29., Průhonice

- Blaškovičová, L., M. Borodajkevyčová, J. Podolinská, S. Liová, L. Lovásová, M. Fabišíková, I. Pospíśilová, Z. Palušová, H. Šipikalová, 2011: Hydrologická ročenka: povrchové vody 2010. SHMÚ, Bratislava, $227 \mathrm{p}$.

- Bojaxhi, F., E. Toromani,, 2016: The Growth of Bosnian Pine (Pinus heldreichii Christ.) at Tree Line Locations from Kosovo and its Response to Climate. South-east Eur for 7 (2): 109-118. DOI: https://doi.org/10.15177/seefor.16-10

- Bojaxhi, F., E. Toromani, 2017: Spatial and Temporal Growth Variation of Pinus heldreichii Christ. Growing along a Latitudinal Gradient in Kosovo and Albania. South-east Eur for 8 (2): early view. DOI: https://doi.org/10.15177/seefor.17-10

- Bugala, M., M. Migas, 2011: Premenlivost kvalitatívnych znakov kmeňov, (Alnus incana (L.) Moench.) v oblasti Polany. Acta Facultatis Forestalis, 53: 7.-18. Zvolen

- Bugala, M., J. Pittner, 2010: Analýza štrukturálnej diverzity porastov jelše lepkavej (Alnus glutinosa (L.) Gaertn.) na území VŠLP TU vo Zvolene, Acta Facultatis Forestalis Zvolen, 52 (1): 43.-54., Zvolen

- Bugala, M., Z. Parobeková, 2016: Influence of altitudinal gradient on productive potential of grey alder (Alnus incana (L.) Moe- nch) in the Bukovské Vrchy Mts., Slovakia, Zprávy lesnického výzkumu, 61(3): 125.-131., Jíloviště

- Cook, E.R., 1985: A time-series analysis approach to tree ring standardization, Ph.D. Dissertation. University of Arizona, 171 p., Tucson.

- Cook, E.R., L.A. Kairiukstis, 1992: Methods of dendrochronology: applications in the environmental sciences, Kluwer, 394 p., Dordrecht.

- Cropper, J.P., 1979: Tree-ring skeleton plotting by computer, TreeRing Bulletin, 39: 47. -59.

- Dittert, K., J. Wötzel, B. Sattelmacher, 2006: Responses of Alnus glutinosa to anaerobic conditions - mechanisms and rate of oxygen flux into the roots, Plant Biology, 8: 212.-223.

- Douda, J., A. Čejková, K. Douda, J. Kochánková, 2009: Development of alder carr after the abandonment of wet grasslands during the last 70 years, Annals of Forest Science, 66: 712. doi: $10.1051 /$ forest/2009065.

- Fabrika, M., H. Pretzsch, 2011: Analýza a modelovanie lesných ekosystémov, Technická univerzita vo Zvolene, 599 p., Zvolen.

- Fang, K., D. Chen, X. Go, R. D’Arrigo, N. Davi, 2015: Influence of non-climatic factors on the relationships between tree growth and climate over the Chinese Loess Plateau, Global and Planetary Change, 132: 54.-63.

- Harris, I., P.D. Jones, T.J. Osborn, D.H. Lister, 2014: Updated highresolution grids of monthly climatic observations - the CRU TS3.10 Dataset, International Journal of Climatology, 34: 623.642.

- Krstinić, A., J. Gračan, D. Kajba, 2002: Alnus spp. genetic resources conservation strategy: Noble Hardwoods Network, Report of the fourth meeting, 4-6 September 1999, In: J. Turok, G. Eriksson, K. Russell, S. Borelli (eds.), Gmunden, Austria, and the fifth meeting, 17-19 May 2001, Blessington, Ireland, IPGRI, pp. 44.- 49., Rome

- Li, X., E. Liang, J. Gričar, P. Prislan, S. Rossi, K. Čufar, 2012: Age dependence of xylogenesis and its climatic sensitivity in Smith fir on the south-eastern Tibetan Plateau, Tree Physiology, 33: 48.-56. doi:10.1093/treephys/tps113.

- Linderholm, H.W., 1999: Climatic and anthropogenic influences on radial growth of Scots pine at Hanvedsmossen, a raised peat bog, in south central Sweden, Geografiska Annaler, Series A, 81 (1): 75.-86. doi: 10.1111/j.0435-3676.1999.00050.x.

- Linderholm, H.W., M. Leine, 2004: Assessing twentieth century tree-cover changes on a southern Swedish peatland combining dendrochronological and remote sensing methods, Wetlands, 24: 357.-363.

- Lukáčik, I., 1996: Biodiverzita a zdravotný stav porastov jelše lepkavej (Alnus glutinosa (L.) Gaertn.) vo Zvolenskej kotline, In: P. Hlaváč (ed), Biodiverzita $\mathrm{z}$ aspektu lesa a polovníctva, Technická univerzita, Zvolen, pp. 171.-178., Zvolen

- Lukáčik, I., M. Bugala, 2005: Premenlivost', rastová charakteristika a ekológia jelše lepkavej Alnus glutinosa (L.) Gaertn.) a jelše sivej (Alnus incana (L.) Moench.) na Slovensku, Vedecké štúdie 13/2004/A, Technická univerzita, 69 p., Zvolen

- Lukniš, M., J. Bako, J. Berta, O. Ferianc, Z. Feriancová-Masárová, O. Fusán, J. Futák, S. Hejný, A. Jurko, L. Korbel, M. Kurpelová, L'. Mičian, J. Michalko, Š. Petrovič, Z. Schmidt, E. Šimo, F. Vlček, M. Zatko, 1972: Slovensko 2 - Príroda. Obzor, Bratislava, 917 p.

- Marhefka, J., 2014: Restoration of damaged area, Tatry 53(6) Special edition: $32 .-34$.

- Pagan, J., 1996: Lesnícka dendrológia, Technická univerzita, 378 p., Zvolen 
- Pernar, N., E. Klimo, D. Bakšić, I. Perković, M. Rybníček, H. Vavrčík, V. Gryc, 2012: Carbon and nitrogen accumulation in common Alder forest (Alnus glutinosa Gaertn.) in plain of Drava river, Journal of the Forestry Society of Croatia, 136 (9-10): 431. -443.

- Phipps, R.L., J.C. Whiton, 1988: Decline in long-term growth trends of white oak, Canadian Journal of Forest Research, 18: 24.-32.

- Rieger, I., I. Kowarik, P. Cherubini, A. Cierjacks, 2017: A novel dendrochronological approach reveals drivers of carbon sequestration in tree species of riparian forests across spatiotemporal scales, Science of the Total Environment, 574:1261.-1275.

- Rodríguez-González, P.M., J.C. Stella, F. Campelo, M.T. Ferreira, A. Albuquerque, 2010: Subsidy or stress? Tree structure and growth in wetland forests along a hydrological gradient in Southern Europe, Forest Ecology and Management, 259: 2015.-2025. doi: 10.1016/j.foreco.2010.02.012.

- Rozas, V., 2005: Dendrochronology of pedunculate oak (Quercus robur L.) in an old-growth pollarded woodland in northern Spain: establishment patterns and the management history, Annals of Forest Science, 62: 13.-22.

- Rybníček, M., P. Čermák, T. Žid, T. Kolář, 2012: Growth responses of Picea abies to climate in the central part of the Českomoravská Upland (Czech Republic), Dendrobiology, 68: 21.-30.
- Rytter, L., R.M. Rytter, 2016: Growth and carbon capture of grey alder (Alnus incana (L.) Moench.) under north European conditions - Estimates based on reported research, Forest Ecology and Management, 373: 56p.

- Schweingruber, F.H., 1996: Tree rings and environment dendroecology, Haupt, 609 p.,Berne

- Schweingruber, F.H., D. Eckstein, F. Serre-Bachet, O.U. Bräker, 1990: Identification, presentation and interpretation of event years and pointer years in dendrochronology, Dendrochronologia, 8: 9.-38.

- Šmelková, L., I. Sarvašová, 2007: Klíčenie a rast semenáčikov rodu Alnus z peletizovaného semena, In: M. Sarvaš, M. Sušková (eds), Aktuálne problémy lesného škôlkárstva, semenárstva a umelej obnovy lesa. Národné lesnícke centrum, 123.-129., Zvolen

- Speer, J.H., 2010: Fundamentals of tree-ring research, The University of Arizona Press, 508 p., Tucson.

- Vacek, Z., S. Vacek, V. Podrázský, J. Král, D. Bulušek, T. Putalová, M. Baláš, I. Kalousková, O. Schwarz, 2016: Structural diversity and production of alder stands on former agricultural land at high altitudes, Dendrobiology, 75: 31.-44.

- Vukelić, J., D. Baričević, I. Šapić, 2012: Phytosociological characteristics of forests of grey alder (Alnus incana (L.) Moench) in Gorski kotar, Journal of the Forestry Society of Croatia, 21(1): 49. -64 .

\section{SAŽETAK}

U radu se analizira produktivnost i osjetljivost rasta sive johe (Alnus incana (L.) Moench) u sastojini smještenoj na područja oko vodotoka u dolini Belianska, u orografskoj jedinici Velika Fatra Mts. (Slovačka). Cilj ove studije je na temelju dendrokronoloških metoda analizirati proizvodni potencijal sive johe uzduž visinskog uspona, kako bi se utvrdila uzročna veza proizvodnje i ekološkog optimuma, a u srvhu detektiranja klimatskih čimbenika koji utječu na rast sive johe. Uzduž visinskog raspona od 525-705 m n.v. na području istraživanja postavljeno je osam trajnih istraživačkih ploha (slika 1). Na svakoj plohi mjereni su prsni promjer ( $\mathrm{dbh}$ ) i visina stojećih stabala, čiji je dbh $\geq 8 \mathrm{~cm}$ te su odvojene jezgre pojedinih odabranih krošnji. Za mjerenje širine godova korišten je WinDENDROTM software. Pojedine serije godova sinkronizirane su tehnikom Skeleton crtanja i godišnji trend rasta određen je pomoću ARSTAN-a. Korelacija između standardne kronologije i srednjih mjesečnih klimatskih obilježja izračunata je za period 1969-2015 (slika 3). Značajna razlika prosječnom rastu temeljnice (BAIav) može se uočiti među različitim visinskim zonama (slika 2). Najveći BAIav (1661 $\pm 975 \mathrm{~mm}^{2} \mathrm{y}^{-}$ $\left.{ }^{1}\right)$ uočen je u zoni na visini od $605 \mathrm{~m}$ asl (tablica 1). Konstantni pad srednje vrijednosti BAIav uočen je od te zone naviše, odnosno naniže s obzirom na nadmorsku visinu promatranih zona. Istraživanje osjetljivosti rasta na vanjske čimbenike pokazalo je generalno nisku osjetljivost promatrane populacije sive johe (tablica 3). Uopće, radijalni rast sive johe bio je značajno pozitivno uvjetovan jedino temperaturom tijekom travnja, a negativno uvjetovan količinom padalina prethodne vegetacijske sezone (tablica 3, slika 4). Na osnovi analize referentne godine može se ustvrditi da je promatrana populacija dva puta značajno pozitivno reagirala na klimatske uvjete (1970.g. i 1993.g.), a negativno samo jednom (2015.g.) (slika 5). Negativni rast u odnosu na referentnu godinu dogodio se za vrijeme vrućih i suhih vremenskih uvjeta, koji inače pogoduju rastu sive johe, ali je prethodna, ekstremno vlažna vegetacijska sezona izazvala oštećenja na korijenju. Iz toga slijedi da je stanje sustava korijena najznačajniji čimbenik glede radijalnog rasta te značajno ovisi o količini vode prethodne godine. 